\title{
Entre Roma y Jerusalén. Conciencia criolla y elogio a la ciudad de México en la obra de Juan de Viera
}

\author{
Rogelio Jiménez Marce \\ Ciesas, México \\ rojimarc@yahoo.com.mx
}

\begin{abstract}
Resumen
El objetivo del artículo es analizar cómo el sacerdote Juan de Viera utilizaba la loa a la ciudad de México y el guadalupanismo como elementos de identificación del criollismo novohispano, elementos que le permitirían afirmar que la capital del virreinato de la Nueva España estaba destinada a convertirse en la principal ciudad del continente, pues ella encerraba una gran riqueza material y espiritual.
\end{abstract}

Palabras clave: Ciudad de México, siglo XVIII, nacionalismo criollo, guadalupanismo, reformas urbanas, Juan de Viera.

\begin{abstract}
The objetive of article is analyse the form that priest Juan de Viera utilized the praise to Mexico's city and the guadalupanismo as identification elements of novohispan creolism, elements that allow to affirm that capital of the New Spain was destined to converted in the main city of the continent, since she contained great wealth material and spiritual.
\end{abstract}

Key words: Mexico, $18^{\text {th }}$ century, creole nationalism, guadalupanismo, urban reforms, Juan de Viera.

\section{Una pintura y una narración}

En el Museo Nacional de Historia de la ciudad de México, existe un cuadro que representa la entrada del marqués de Croix a la capital del virreinato de la Nueva España. Si se observa con detalle la pintura, se notará que, como composición artística, es muy rica en detalles. El lienzo, digna manifestación del arte barroco novohispano, no muestra espacios vacíos, sino que cada punto es ocupado por una diversidad de personajes que representan a los grupos de 


\section{FRONTERAS}

la sociedad novohispana. En la pintura se advierte que el punto de atención no es el grupo de carrozas que guiaban al virrey Croix a la catedral, sino la intensa actividad que se desarrollaba en la plaza mayor, lugar que se convertía en el centro neurálgico de la capital novohispana ${ }^{1}$. Esta pintura realizada por Rodríguez Juárez en 1766 sirve como telón de fondo para presentar la Breve compendiosa narración de la ciudad de México, obra escrita en 1777 por el sacerdote Juan de Viera, la cual se ubica en un contexto de profundos cambios políticos, ideológicos y espaciales que se van a reflejar en la descripción que hace de la ciudad de México $^{2}$. Esta investigación se sitúa en el ámbito de la historia de las ciudades, y busca a partir del texto de Viera entender la forma en que éste configura su imaginario de la ciudad, imaginario que busca entenderla como una ciudad terrenal y divina ${ }^{3}$. La obra de Viera formaba parte de una amplia tradición de escritos, que entre los siglos XVI y XVIII dieron cuenta de las virtudes $\mathrm{y}$ defectos de la capital del virreinato. Las variantes en las descripciones de la ciudad de México muestran que ningún proceso de observación es objetivo, sino que existe un número infinito de formas de ver el mundo, que derivan de la predisposición del observador, su mentalidad, educación y estado de ánimo.

Si bien es cierto que la percepción es determinada por la estructura social e histórica, cada sujeto enfoca el mundo desde un particular punto de vista. La percepción individual es perspectiva, es decir, no abarca la totalidad, sino que se encuentra determinada por un conjunto particular de intereses y motivos (Dondis 31; Kingman 9; Lowe 66; Rasmussen 33-34). De acuerdo con lo anterior, el texto de Viera se debe entender como un esfuerzo por otorgarle a la ciudad de México un lugar de primera importancia dentro de la geografía cristiana del siglo XVII. La exposición se divide en tres partes: en la primera se hace un recuento del contexto histórico novohispano, en la segunda se mencionan aspectos generales del autor y de la obra, y en la tercera se muestra la doble visión que Viera tenía sobre la ciudad de México.

1 La pintura se encuentra reproducida en el libro de Benítez (102).

2 Una segunda edición de la obra fue realizada en 1992 por el Instituto Mora. En este estudio se utilizó la versión de 1952, aunque también se recurrió a la segunda para observar sus diferencias.

3 La historia de las ciudades busca los rasgos geográficos, históricos, religiosos, arquitectónicos, políticos, económicos y demográficos de las urbes. 


\section{El contexto histórico novohispano}

Después de la derrota española en la guerra de los Siete Años y de la firma de la Paz de París en 1763, la política imperial metropolitana sufrió modificaciones derivadas del hecho de que España había sido desplazada a una potencia de segundo orden. Los ministros de Carlos III estaban conscientes de que era necesario imponer un nuevo orden en las posesiones ultramarinas, para lo cual llevaron a cabo una serie de reformas que tendían a reforzar el poder imperial y, a revitalizar la alicaída economía española. Estas disposiciones fueron implementadas en la Nueva España durante las últimas décadas del siglo XVIII. La política borbónica buscaba incrementar los ingresos de la Corona, a través del cobro de nuevos impuestos y de la conformación de monopolios reales. La política de los Borbones resultó benéfica para el virreinato de la Nueva España, pues la libertad de comercio propició un auge económico favorable para los comerciantes de la ciudad de México. A la par de las modificaciones administrativas y económicas, se llevó a cabo un reordenamiento espacial de la capital del virreinato, medida que reflejaba los cambios que se producían en las principales capitales europeas. Para los ilustrados era de suma importancia cambiar el aspecto físico y de servicios de las ciudades. Aunque la ciudad de México había sufrido importantes transformaciones en el siglo XVII, ahora se planteaba un cambio profundo que afectaba su estructura espacial en el ámbito eclesiástico y civil. Las modificaciones en el ámbito eclesiástico escondían una finalidad política. En 1753, la metrópoli ordenó la secularización de los curatos de indios, con el fin de limitar las prerrogativas del clero regular cuyo ministerio autónomo era visto por la Corona como un obstáculo para su política de centralización (Benítez [98]; Bonet [15-17]; Brading [Los orígenes 30, 38]; Castro [97, 103, 106, 110]; Galán [255]; Gutiérrez [84, 91, 93]; La Maza [La ciudad. 7, 58]; Lepetit [9, 114]; Solano ["El núcleo" 18-19]; Taylor [38]; Viqueira $[15,17])$.

El clero regular se negó a obedecer las disposiciones metropolitanas, lo que provocó que sus relaciones con la Corona se volvieran distantes. El clero regular tenía bajo su jurisdicción siete parroquias, mientras que el clero secular sólo poseía cuatro. Con la expulsión de los jesuitas, acaecida el 25 de junio de 1767, comenzó el proceso de secularización de las iglesias. La alianza entre el clero secular y la Corona resultó benéfica para ambas partes. El primero consolidó su riqueza bajo el amparo de la administración real, en tanto que la Corona aumentó sus percepciones y logró tener injerencia en la administración del bautismo, del matrimonio y de la extremaunción. Después de la 


\section{FRONTERAS}

secularización de las parroquias, se buscó resolver el problema de superposición de sus límites territoriales. El arzobispo Lorenzana le encargó a José Antonio de Alzate que elaborara un proyecto de distribución de las mismas. Alzate propuso dos soluciones: la formación de cuatro nuevas parroquias (San Sebastián, Santa Ana, Salto de Agua y Santo Tomás) y que la ordenación se basara en cuestiones espaciales y no raciales. El plan fue aprobado en 1771. La transformación del espacio eclesiástico se complementó con una nueva configuración del espacio civil, tarea que fue realizada entre 1782 y 1789 por los virreyes Martín de Mayorga y Revillagigedo. La ciudad fue dividida en ocho cuarteles mayores y 32 menores. La nueva distribución, civil y eclesiástica, eliminó de facto la disposición que prohibía que indígenas y españoles compartieran los mismos espacios. La capital del virreinato sufrió un proceso de renovación entre 1730 y 1780, derivado del auge minero, comercial e industrial. Se construyeron ostentosos edificios, se rehabilitaron otros, se mejoró la Alameda, y se construyeron dos nuevos paseos (Abascal [30, 34, 37]; Alberro [167-168]; Dávalos [9, 19-20]; Davis [140, 192]; Galindo [321, 324]; Gortari y Hernández [49]; Gutiérrez y González [91]; Lafaye [156, 159]; La Maza [La ciudad 44]; Lombardo [109-110]; Orozco [212]; Solano [Ciudades 92-93, 146, 153, 231]; Ramos [119]; Rubial [La Nueva 69, La plaza 30, 123, 129, "La Sociedad" 37,69]; Serrera [75]).

\section{La obra de Juan de Viera}

La Breve compendiossa narración de la ciudad de México, corte y cabeza de toda la América Septentrional, escrita por Juan de Viera en 1777, forma parte de una serie de obras que durante los siglos XVII y XVIII se propusieron describir la ciudad de México. La lista de estos libros es larga e incluye calendarios, manuales y guías de forasteros y escritos de diversa índole. Entre estos textos se destacan: Theatro Mexicano (1698), de Agustín de Vetancourt; Sitio, naturaleza y propiedades de la ciudad de México (1718), de Diego Cisneros; Extractos de los autos de diligencias y reconocimientos de los ríos, lagunas, vertientes y desagües de la capital de México y su valle (1748), de José Francisco de Cuevas; Suplemento del theatro Americano (1755), de José Antonio de Villaseñor; Exacta descripción de la magnifica corte mexicana, cabeza del nuevo americano mundo, significada por sus esenciales partes para el bastante conocimiento de su grandeza (1768), de Juan Manuel de San Vicente; Descripción de una parte de la Nueva España (1777), de Antonio de Ulloa, y Discurso sobre la policía de México (1778), de Baltasar Ladrón de Guevara. Del libro de Juan de Viera existen dos versiones: una se encuentra en la ciudad de 
México y la otra en París. Gonzalo Obregón piensa que el texto original es el que se resguarda en México y el de París es una copia que se realizó en 1778, conclusión a la que llegó después de comparar los libros. El que se encuentra en México tiene una portada cuyos motivos datan de fines del siglo XVI y tiene un epílogo "del que aprovechó Viera ciertos elementos en su redacción definitiva incorporándolos al prólogo"; en tanto que la versión parisina contiene más datos pero el autor suprimió algunos párrafos y no incluyó los grabados de la guadalupana (Serrera 88; Solano, Ciudades 229 , Las voces $12-15)$.

La narración de Viera se inscribe dentro de la gama de manuales o guías de forasteros, los que tenían la finalidad de ubicar a los viajeros dentro de la ciudad, y darles a conocer su funcionalidad. A diferencia de los manuales europeos, Viera no incluyó una descripción de los personajes notables de la ciudad, y tampoco incorporó mapas que dieran cuenta de la ubicación de los lugares, pero sí trató de determinar el número de habitantes con los que contaba la capital del virreinato, y proporcionó una detallada información de sus principales edificios. Al igual que otras guías que se produjeron en esos años, la de Viera buscaba mostrar que la ciudad de México tenía las condiciones necesarias para gobernarse por sí misma. Una de las virtudes del libro del sacerdote era su excelsa pluma. El autor utiliza la riqueza del detalle y los juegos metafóricos, para hacer amena la lectura de su libro, pues su intención era agradar al lector y no sólo realizar un informe utilitario de la ciudad. En algunas ocasiones, recurrió a la "tópica de lo indecible", estrategia retórica que se basa en una supuesta incapacidad de perorar sobre un tema, pero que tiene la finalidad de hacer creer al lector que todo lo que se dice es verdadero. El estilo de Viera se sitúa dentro de la tradición retórica barroca. El barroco representa el movimiento, el dinamismo y la libertad de expresión formal, que encuentra, tanto en el halago como en las apariencias, su elemento de sustento. Se puede entender al barroco como una exaltación a los sentidos y, como una representación teatral, un mundo de apariencias, una gran fiesta en la que cada individuo desempeñaba un papel (Baker 57; Lamadrid 9,13-15; Moreno 42; Quirarte ix; Rivera 14).

La libertad de creación y la prosperidad se trasladaron a las fachadas, a los retablos y a los altares, lugares en los que "lo infinito e indefinido, lo cotidiano y banal" tendrían la oportunidad de reflejarse. La escritura barroca al igual que la arquitectura buscaba ser una demostración y una apología de lo propio. Ésta se caracterizaba por el uso de "largos y complicados párrafos" y de "frases larguísimas con abundantes metáforas", en las que se buscaba expresar 


\section{FRONTERAS}

"el dominio de la forma por la forma misma" y en las que se ponderaba al extremo lo inverosímil, puesto que los contenidos semánticos rebasaban las expresiones gramaticales. La "extravagancia de la dicción", el "estrafalario rebuscamiento", el "alambicado eufemismo", la "delirante hipérbole" y la "enrevesada tenebrosidad de la metáfora" eran elementos que se presentaban en los textos de la mayor parte de los autores del barroco novohispano. Los malabarismos del lenguaje provocaban que las palabras tuvieran diversos significados. Los escritores novohispanos recurrieron a la mitología helénica, la patrística y la Sagrada Escritura, para encontrar un sustento de sus ideas; rasgo que se advierte con claridad en el texto de Viera, quien utilizaba el pasado grecolatino y referencias bíblicas como una forma de demostrar la grandeza de la ciudad de México. Viera era un excelente observador, cualidad que le permitió describir con detalle el funcionamiento de la capital del virreinato y de sus alrededores. Su narración no sólo se basaba en el dominio que tenía de la ciudad, sino que también recurrió a distintas fuentes para proporcionarle credibilidad a su narración: obras sobre la ciudad, archivos de algunas congregaciones religiosas y de instituciones civiles (Armillas y Solano [122]; Carrillo [26, 29]; P. González [147]; Kurnitzky y Echeverría [15]; La Maza [El guadalupanismo 160]; Leonard [54]; Manrique [5, 6, 8]; Osorio [128-132]; Urbina [82-83]).

El que Viera hiciera explícito el uso de materiales impresos, ha ocasionado que Gonzalo Obregón y Ramón María Serrera traten de ubicar el texto que le sirvió de sustento. Obregón piensa que el sacerdote se apoyó en la Exacta descripción de la magnifica Corte Mexicana (1768) de Juan Manuel de San Vicente, mientras que Serrera considera que fue el Suplemento del Theatro Americano (1755) de José Antonio de Villaseñor. No existe duda de que el sacerdote conocía los dos manuscritos y que le sirvieron como fuente de información, pero pretender que su escrito es una simple copia constituye una falta de respeto a un hombre que no se limitó a describir la capital del virreinato y sus alrededores, sino que buscó darle un sentido ideológico a su obra para justificar la causa criolla. La intención última del sacerdote era demostrar que la ciudad de México tenía la capacidad de convertirse en la cabeza del reino americano. Tampoco se debe pasar por alto que la narración del sacerdote daba cuenta del proceso de renovación que vivía la ciudad de México. Este libro refleja las primeras transformaciones de una capital que se renovaba bajo los postulados ilustrados, los mismos que serían impulsados de manera definitiva por los virreyes Martín de Mayorga y el segundo conde de Revillagigedo, entre los años de 1782 y 1794 (Gutiérrez y González 107; Obregón 10-11; Serrera). 


\section{El autor}

Juan de Viera nació en la ciudad de Puebla entre los años de 1715 y 1720. A los cinco años llegó a la ciudad de México, en la que estableció su residencia de por vida ${ }^{4}$. Estudió en la Real y Pontificia Universidad de México. Tenía una buena formación académica como se puede observar por sus conocimientos sobre la cultura grecolatina. Así, para demostrar su afirmación de que había grandes artistas en la Nueva España, Viera decía que los pintores eran émulos de Apeles, los escultores como Lisipos, Mirón el Medo y Bupalo Lacedemonio, orfebres como Porfirión y alfareros como el ateniense Corebo o Dibutades Ciconio". Su sapiencia provocó que Gonzalo Obregón lo considerara una de las "piedras fundamentales" de "la historia del arte de México", afirmación que resulta exagerada pero que demuestra que el autor no era un simple aficionado que cantaba loas a los novohispanos, sino un hombre que buscaba mostrar la magnificencia del arte americano. Después de que salió de la Universidad, Viera dedicó sus primeros años al "trabajo evangélico", pues administraba los sacramentos, predicaba y confesaba. Con la expulsión de los jesuitas en 1767, los colegios de San Pedro y San Pablo, San Ildefonso y la Profesa fueron cerrados. En 1770, se determinó que San Pedro y San Pablo y San Ildefonso se reunieran en un mismo establecimiento. Viera sería nombrado administrador del mismo, gracias al apoyo que le dispensaron el arzobispo Francisco Antonio de Lorenzana y el virrey Antonio María de Bucareli, puesto que desempeñaría entre 1770 y 1780, es decir, Viera escribió su texto cuando era miembro de la alta esfera educativa (Abascal 37; Orozco 177; Ramos 121). El propósito central de su narración era demostrar que las "grandezas" que poseía la capital novohispana eran verdaderas, pues a pesar de que los “europeos" las conocían, no querían admitirlas.

Explicaba, con cierto tono irónico, que redactó este texto "a persuasivas instancias de algunos amigos europeos, a quienes no les preocupa la ciega pasión del espíritu nacional". Viera pensaba reivindicar a una América que había sido humillada por algunos pensadores europeos que la consideraban una tierra "inculta", "llena de errores y supersticiones", de "encantos" y de "hechisserias". El autor consideraba que ese miedo infundado provocaba que los euro-

4 Obregón calcula que Viera nació entre 1719 y 1720, debido a que el autor señalaba que escribió su libro a los 58 años, pero la cifra es incorrecta pues el sacerdote mencionaba que tenía 58 años de residir en la capital del virreinato. A este dato se le debía agregar los cinco años que Viera vivió en Puebla, por lo que Viera escribió su texto a los 63 años y lo más probable es que haya nacido entre 1714 y 1715 (Obregón 10-12). 


\section{FRONTERAS}

peos viajaran con un gran número de reliquias para defenderse de "encantos imaginarios" y, que sus familiares pensaran que un viaje a la Nueva España podría culminar con la muerte de los viajeros. Las ideas que Viera rechazaba formaban parte del conjunto de imágenes que los europeos tenían de los americanos. La postura del sacerdote denotaba su pertenencia a lo que se ha denominado la "generación de los treinta", la que estaba conformada por un grupo de criollos mexicanos que se insertaron en un clima espiritual y de preocupaciones intelectuales propias, como resultado de una educación y experiencias comunes. Lafaye menciona que los hombres que pertenecían a esta generación nacieron en los primeros años del siglo XVIII, por lo que se encontraban en la madurez de su vida en el momento en que se produjo el impacto de la Ilustración. La mayoría de ellos habían abrazado la carrera profesional o eclesiástica. Eran un grupo homogéneo que expresaron a través de sus textos "la imagen de la patria mexicana que llevaban dentro". Ellos se caracterizaban por cuatro rasgos: su barroquismo literario, su conocimiento del pasado clásico, su defensa de lo propio y su culto a la guadalupana (Lafaye 129-132, 171; Serrera 11) .

Serrera considera que en esta generación se encuentran presentes dos preocupaciones: la búsqueda de una identidad cultural y una creciente actividad científica que se manifestó en: la fundación de un periódico (Gazeta de México), en el estudio del pasado indígena y en la redacción de la primera geografía regional de México (Theatro Americano). Para los criollos era imprescindible demostrar sus logros, puesto que los europeos afirmaban que los americanos eran unos "miembros degenerados" de la humanidad. Así, por ejemplo, Manuel Martí señalaba en sus Cartas Latinas que la Nueva España era un "desierto literario", carente de intelectuales y buenas bibliotecas. Como respuesta, Juan José Eguiara y Eguren elaboró su Biblioteca Mexicana, en la que mostró los logros intelectuales de los criollos novohispanos. La "generación de los treinta" no sólo salió en defensa de los criollos, sino de los americanos en general, ante las versiones que difundían los pensadores europeos ilustrados acerca de la degeneración que se experimentaba entre las especies animales y vegetales del Nuevo Mundo. Los escasos conocimientos que los europeos tenían sobre los americanos — derivado de la política española de no permitir que los extranjeros pisaran sus posesiones ultramarinas - era un caldo de cultivo perfecto para reproducir ideas fantásticas acerca de ellos. La cerrazón

Aunque Bernabé Navarro considera que esta generación se debe ubicar entre 1700 y 1750, Monelisa Pérez Merchant y Roberto Moreno de los Arcos apoyan la temporalidad propuesta por Lafaye y Serrera. 
de las autoridades españolas y la ausencia de obras "modernas" que mostraran los adelantos de los americanos propiciaron que se esparcieran ideas respecto a que América era un lugar en el que las cosas más aberrantes podían suceder; ideas que derivaban de algunos escritos de viajeros que tuvieron la oportunidad de viajar al continente americano (Brading, Los orígenes 28-30; Clavijero xviii; Puccini 76-77; Serrera 7-10, 12, 17)6.

Ese fue el caso del religioso irlandés Thomás Gage cuyo Viaje a la Nueva España (1699-1700) sirvió como fuente para encontrar evidencias de la supuesta degeneración de los americanos. Unas décadas después, el religioso español Francisco de Ajofrín en su Diario de viaje a la Nueva España (1765) daría cuenta de lo que consideraba un comportamiento distinto de los americanos.

Entre los principales promotores de las idea de la degeneración de los americanos se encontraban Buffón, Cornelius de Pauw, Guillaume Thomas Raynal y William Robertson. Buffón sostenía que como los americanos no habían vencido la hostilidad del ambiente natural, se habían vuelto "débiles", "frígidos" y con "escasa inteligencia". Aunque Buffon le dio coherencia científica a los perjuicios en torno al Nuevo Mundo, serían De Pauw, Raynal y Robertson los que divulgarían las ideas sobre la degeneración. De Pauw afirmaba que el atraso del continente americano era producto del clima "nocivo" que hacía que los hombres fueran débiles, carentes de sensibilidad, de buen gusto y de inteligencia. La posición europea fue impugnada por los intelectuales americanos. Tomás Jefferson publicó una lista de medidas de las especies animales americanas, en tanto que Benjamín Franklin hizo una amplia exposición de los logros de la sociedad estadounidense. En el caso novohispano, los jesuitas Francisco Javier Clavijero, Andrés Cavo y Francisco Javier Alegre escribieron una serie de estudios que buscaban rehabilitar la imagen de la América española (Ajofrín [68-69]; Brading [Los orígenes 33-34, 44, 46]; Gage [132-133, 261]; Gerbi [3, 10-11]; Lafaye [171]; Marchetti [26, 28-30, 33, 37, 66]).

En su Historia antigua de México, Clavijero sostenía que el clima americano era "generoso" y que los habitantes no se podían considerar degenerados, pues

\footnotetext{
Brading considera que la obra de Eguiara y Eguren constituyó la culminación de un ciclo de cultura criolla. Clavijero también se propuso demostrar que en la Nueva España había escritores de primera línea, entre los que sobresalían Veracruz, Hortigosa, Naranjo, Cervantes, Sariñana, Siles, Singüenza, Bermúdez, Eguiara, Miranda y Portillo, autores "excelsos" que "harían honor a las más célebres academias de la docta Europa", por lo que era injustificado afirmar que América carecía de hombres de talento.
} 


\section{FRONTERAS}

las altas civilizaciones indígenas daban cuenta del desarrollo alcanzado en la agricultura, las artes y la ciencia. Los trabajos tendientes a destruir la mala imagen de América sirvieron para que los europeos contaran con un cuerpo de saber enciclopédico, que contribuyó a satisfacer su "sed de exotismo" (Brading [Los orígenes 36, 45-46, 48; Orbe 463,483]; Clavijero [xxi, xxxiiixxxiv]; Gerbi [67-68, 71, 74, 81-82, 247, 252-254]; Marchetti [38, 50, 58, 61, 68, 71, 112-113, 118]; Rubial [La Nueva 44]).

A diferencia de otros autores americanos, Viera no buscaba polemizar, e indicaba que sólo tenía la intención de mostrar que América era una tierra que embelesaba por su "abundancia, riqueza y hermosura", virtudes que se podían apreciar en todo su esplendor en la capital de la Nueva España. La abundancia se reflejaba en la gran cantidad de alimentos que entraban a los mercados de la ciudad; la riqueza, en la magnificencia de los edificios y en el modo de vida de la mayor parte de sus pobladores, y la hermosura en el entorno natural que rodeaba a la ciudad. Viera buscaba demostrar que existía un "genio americano" que se expresaba en la obra de los científicos, pintores y artistas que vivían en la ciudad de México, tales como los pintores Francisco Vallejo y Miguel Cabrera y el artesano José de la Borda. Viera destacaba que los anteriores pintores no eran los únicos que habían sobresalido, pues se podían presumir las obras de 43, 32 de los cuales eran "antiguos" y once "modernos". Entre los "antiguos" sobresalían Luis Juárez, Juan Correa y Cristóbal de Villalpando. En el ámbito musical destacaba la capilla de música de la Catedral, la cual, según el autor, no tenía rival en América ni en la misma España, pues más bien parecía un "coro de ángeles" que de hombres". La abundancia, riqueza, hermosura y capacidad de sus hombres mostraban que la ciudad de México debía considerarse la más importante de América, pues no existía otra que tuviera sus mismos dones.

\section{Una aclaración necesaria}

Viera estaba consciente de que su escrito podía recibir severas críticas de tres tipos de personas: las que lo censurarían por su carácter sacerdotal, las que realizarían los "sabios" para corregir sus errores y las que harían los "ignorantes" que buscarían magnificar sus fallas. A él no le importaban las críticas, sino que buscaba convencer a sus lectores de que había escrito su libro para rendir un tributo a la ciudad de México, pues deseaba relatar con "ignorancia y corta expresión" las maravillas de la urbe que lo acogió desde pequeño. Viera declaraba que había nacido en Puebla para evitar que sus detractores lo consideraran un "embustero", un "falaz" y un "trapecista", calificativos que se 
les daba comúnmente a los poblanos (Ajofrín 55; Penny 80-81)7. El sacerdote reconocía que la ciudad de Puebla era "hermosa", pero "sus grandezas" eran "escasas y limitadas", a diferencia de la ciudad de México que tenía "incomparables" virtudes. Para mostrar de una manera más adecuada la relación que guardaban, desde su perspectiva, las dos ciudades, Viera recurrió a una metáfora en la que la primera se identifica con la Luna y la segunda con el Sol, es decir, una era un pequeño satélite, mientras que la otra era el eje del sistema. La actitud de Viera reflejaba el conflicto que se suscitó entre estas ciudades por alcanzar la supremacía dentro del virreinato. Un antagonismo que culminó a mediados del siglo XVIII con la derrota de la "orgullosa" Puebla, ciudad que alcanzó un notable desarrollo económico durante el siglo XVII, lo que sirvió para que buscara disputarle el poder político a la misma capital (Lomelí 7678; Villa Sánchez 11, 242; Villaseñor 241-243).

Ante las inundaciones que sufrió la ciudad de México en la primera mitad del siglo XVII, se sugirió que se trasladara el gobierno virreinal a Puebla, pero la propuesta no se llevó a cabo. Una pretensión de la elite poblana era que la Corona le permitiera elegir a los miembros de su Cabildo, pretensión que fue rechazada, porque la aprobación significaba la independencia de la ciudad respecto del poder virreinal. La elite poblana utilizó la religión, para demostrar que tenía un lugar privilegiado en el mundo. La leyenda de que la ciudad había sido trazada por los ángeles no sólo mostraba el orgullo de sus habitantes, sino también los elevados designios que se reservaban para su ciudad. La erección de un considerable número de conventos e iglesias tenía la finalidad de que éstas se convirtieran en "una fuente de orgullo e identificación común" y, de que con la exaltación de los valores religiosos se pudiera competir con la ciudad de México por la hegemonía. Con la consagración del convento de la Concepción en 1617 y la celebración de la fiesta de la Inmaculada Concepción en 1619, el Cabildo angelopolitano buscaba mostrar que la capital y Puebla tenían la misma categoría (Alberro 157; Arenas 29-30; Lomelí 100-102; Loreto 90-94). Lo anterior explica el porqué Puebla se mostró contraria a la creación del Patronato de Guadalupe del Tepeyac, pues ello representaba "en el plano trascendental la supremacía de la 'ciudad imperial de México' en Nueva España”. La decadencia comercial de Puebla en el siglo XVIII —ocasionada por las epidemias y la fuerte competencia de otras regiones- propició el fin del conflicto entre las dos ciudades (Benítez 39; Lafaye 141). La enconada disputa entre las urbes y la mala fama de los poblanos fueron las razones que explica-

Ajofrín decía que la mala fama de los poblanos se conocía en toda América, afirmación que sería confirmada en 1824 por el comerciante inglés William Penny. 


\section{FRONTERAS}

ban por qué Viera prefirió evitar su vinculación con ellos, a fin de evitar que su texto fuera menospreciado.

\section{Entre el cielo y la tierra: la ciudad de México}

El texto de Viera describe dos facetas de una misma ciudad: una terrenal, que era digna representante del mundo americano y una espiritual, que bajo la égida de la Virgen de Guadalupe podía llevar a la primera a alcanzar un puesto de primera importancia en el mundo cristiano. La idea de la ciudad de México como regalo de la Madre de Dios representaba uno de los puntos capitales del criollismo novohispano, idea que, según ellos, mostraba la preferencia que Dios tenía por la capital novohispana. La narración de Viera se inscribe dentro del género de la crónica, porque la voz que narra se inserta en el nivel homodiegético (primera persona gramatical) del discurso, es decir, el narrador se convierte en protagonista en tanto toma una doble faceta: es objeto de lo narrado al incluirse en la trama del texto, y es sujeto de la narración pues se ubica fuera del mismo y le confiere verosimilitud (Carreño 508; Castañón y Millán 22; Obregón 9-10; Silva ix- xiii).

\section{La "Roma" del Nuevo Mundo}

Una de las aspiraciones de los pensadores novohispanos fue convertir a la ciudad de México en la "Roma" del Nuevo Mundo, pretensión que no resulta extraña, si se piensa que Roma representaba el modelo ideal de la urbe. Las aspiraciones criollas se fundamentaban en la idea de que Roma y la ciudad de México eran ciudades con un pasado imperial. La grandeza de una ciudad, bajo la idea imperial, se medía por la magnificencia de sus edificios, el número de sus hijos ilustres y la abundancia de sus bienes; tres imágenes que estaban presentes en la narración de Viera, quien advertía que en Roma se encontraba la sede del poder religioso humano, pero la ciudad de México era la sede del poder religioso espiritual, debido a la protección que les dispensaba la virgen de Guadalupe. Viera se adhería a las ideas de Francisco Javier Carranza, Francisco de Castro y José Antonio de Villerías, para quienes la Nueva España se convertiría en la "Roma del Noroeste", y el Tepeyac sería la residencia de los papas; pensamientos que serían retomados por Fernández de Salvador en 1805 y por Beristáin y Souza en 1809. Al igual que Francisco Javier Carranza, Agustín de Vetancourt y Manuel Bocanegra, Viera recurría a la evocación de las ilustres urbes del pasado clásico para asimilar sus características a las de la ciudad de México. La vinculación que los criollos establecían entre las ciudades mitológicas y la capital del virreinato denotaba su deseo de mostrar 
la grandeza de una urbe que hundía sus raíces en la antigüedad, razón por la que no debe extrañar que Viera asociara la ciudad española con la "noble Thenosticlan", es decir, el sacerdote al igual que otros pensadores criollos vinculaba el pasado indígena con el hispano (Osorio 187-188, 211; Rubial, La plaza $15-16)^{8}$.

El autor pensaba que la ciudad de México era una "émula de la antigua Troya" por su disposición física y porque en ella se resguardaba a la virgen de Guadalupe que era la mayor belleza del mundo, motivo por el que también se le debía considerar la "Nueva Jerusalén". A decir de Viera, la ciudad de México tenía la misma "hermosura", riqueza y magnificencia que Tebas y Memfis, pero las superaba en "grandeza, edificios, fertilidad, abastos e imponderables abundancias". Viera mencionaba que la capital se ubicaba a los $19^{\circ} 59^{\prime}$ de latitud y $274^{\circ} 19^{\prime}$ de longitud. Su planeta regente era Venus que se situaba en el signo de Capricornio. La opinión de Viera difería de la de Juan Antonio de San Vicente, quien en su Exacta descripción de la Magnifica Corte Mexicana manifestaba que el planeta dominante era Saturno y los signos eran Tauro, Leo y Capricornio. Viera eligió Venus para demostrar que la belleza de la ciudad estaba escrita en las estrellas. El sacerdote manifestaba que el emplazamiento de la urbe evidenciaba su situación privilegiada, pues el "bellísimo lago" era "un abreviado diseño del paraíso". Aunque los lagos de Texcoco, Chalco y San Cristóbal tenían una menor capacidad y extensión que las aguas del Nilo, poseían "más tersas y cristalinas aguas". De los tres lagos circundantes, el más importante era el de San Cristóbal, pues dotaba de agua al centro de la ciudad, y hacía que crecieran "bosques de pinos, cipreses, fresnos y álamos". Viera no mencionaba que las obras de desagüe habían ocasionado que los lagos se alejaran de la ciudad, aunque Joaquín Velázquez de León indicaba en 1775 que el área lacustre abarcaba 124.000 hectáreas (Benevolo [4: 70]; Bonet [17]; Brading [Orbe 407, 423]; Lafaye [149-152,155]; La Maza [El guadalupanismo 68]; Lepetit [17]; Manrique ["La ciudad" 259]; Osorio [217]; Solano [Ciudades 228-229]; Taylor [244]; Valle [387]).

La ciudad medía una "legua y cuarto" de oriente a poniente y, una legua de norte a sur. Varias calzadas y garitas permitían el ingreso de los caminantes. La capital tenía una composición geométrica uniforme, de tal forma que cons-

Tanto Roma como Venecia se convirtieron en los paradigmas urbanos que definieron a la ciudad de México. Pedro de Gante y Hernán Cortes tenían en mente a la "ciudad eterna" cuando delinearon los barrios de la ciudad, razón por la que las parroquias de indios recibieron el nombre de los santos protectores romanos. 


\section{FRONTERAS}

tituía un cuadrado. Lo que el sacerdote describía era el modelo de damero de calles rectilíneas que fue utilizado por los españoles en la fundación de la mayor parte de las ciudades americanas, el cual se caracterizaba por su uniformidad, pues consistía en una serie de manzanas iguales que conformaban un cuadrado. Viera reconocía que la distribución espacial había sido rebasada por las actividades de los individuos, al grado que en algunas zonas se habían excedido los límites de la ciudad. Un ejemplo de esa situación era la calle que iba del Hospital de San Lázaro a la villa de Tacuba, la que tenía una extensión de tres leguas y se extendía más allá de la traza de la urbe (Aguilera [65, 67, 97]; Benevolo [4:112, 122]; Bonet [180, 182]; Hardoy [20]; Jáuregui [20]; Kurnitzky y Echeverría [49]; Malamud [261]; Morse [319]; Solano [Ciudades 160-163; Normas xxxi]) .

\section{Las plazas como los motores de la ciudad}

La ciudad descrita por Viera situaba sus principales puntos de actividad en las plazas; las mismas que concentraban los edificios representativos del poder religioso, civil y comercial; es decir, la plaza se convertía en el núcleo estructurador de la urbe. Las principales actividades de la urbe se desarrollaban en tres plazas: la mayor, la del Volador y la de Santo Domingo. El corazón de la ciudad de México se localizaba en la plaza mayor, lugar en el que se ubicaban la Catedral, el Real Palacio y los centros mercantiles (Portal de las Flores, Portal de Mercaderes, el Parían y el Baratillo). Viera inició la descripción de la ciudad en las puertas del Real Palacio, lo que evidenciaba que el autor reconocía la primacía del orden civil sobre el religioso. El recuerdo de la expulsión de los jesuitas estaba fresco y el sacerdote no quería que su libro le causara problemas del algún tipo. Resulta interesante observar que el autor magnificaba las virtudes de los edificios de la plaza mayor, pues desde su perspectiva el Palacio podía servir de residencia al rey y la catedral era más imponente que las europeas. Al enfatizar la excelsitud de estos edificios, Viera buscaba mostrar que la ciudad de México podía convertirse, sin ningún problema, en el asiento del poder real, es decir, de forma implícita se sugería que se tenía la capacidad para gobernarse a sí misma (Aguilera [69, 75, 82]; Benevolo [3: 49, 4: 112]; Bonet [39, 80, 165, 175, 178-180, 182, 187]; Hardoy [319-320,

9 Las ciudades hispanoamericanas fueron fruto de un modelo urbanístico que buscaba una perfecta distribución del espacio. La forma geométrica de ciudad se fundó en tres tradiciones: la española derivada de la experiencia romana y helenística; la renacentista que buscaba la ciudad ideal, y la indígena. Existen dos modelos de ciudad reticular: ortogonal, en el que las calles forman ángulos rectos y su plaza mayor es rectangular, y cuadrícula, en el que las manzanas y calles forman un entramado de iguales dimensiones. 
326]; Gutiérrez [281, 293-300]; Margadant [74]; Solano [Ciudades 155, 158159, 175, 183; "Las voces" 29]) ${ }^{10}$.

Que el autor prestara gran atención a los vendedores del Baratillo y del Parián revelaba su deseo de mostrar la pujanza económica que se vivía en la capital virreinal y, la gran diversidad de productos que se encontraba en ella; razón por la que pensaba que estos mercados constituían "un abreviado epílogo de las maravillas" (Aguilera 80; Solano, Ciudades 145,191)11. Para que los lectores no consideraran que sus apreciaciones eran exageradas, el religioso presentaba una lista de 98 tipos de frutas y 42 de pescados.

A fin de abastecer los requerimientos diarios de la urbe, el sacerdote decía que se movilizaban entre 2.000 y 10.000 canoas. El "excesivo y crecido" abasto se explicaba por la enorme población que habitaba la capital. El autor no exageraba en su apreciación. Francisco de Ajofrín mencionaba en 1765 que en la ciudad de México se consumían anualmente 300.000 carneros, 15.500 reses, 30.000 cerdos, 2.000 .000 de arrobas de harina y 160.000 fanegas de maíz (Lozoya 24$)^{12}$. El Parián demostraba el poderío económico de la capital, pues las mercancías que ahí se encontraban ascendían a más de 30.000.000 de pesos. La intensa actividad económica y el creciente aumento de población eran dos aspectos que resaltaban en la narración de Viera, aspectos que, de acuerdo con Bernard Lepetit, servían como parámetros para definir la importancia de las ciudades a fines del siglo XVIII (Ajofrín 59; Galindo 325; Lepetit 20, 22-23) ${ }^{13}$. La segunda plaza en importancia, desde la perspectiva de Viera, era la del Volador. En ella destacaba la universidad novohispana, la misma que según el

10 La plaza mayor constituye el principal aporte de los españoles a la urbanística hispanoamericana. Aquélla se convirtió en el centro geométrico que determinaba la armazón urbana y en ella se concentraba el poder civil, religioso y administrativo; situación que respondía a la necesidad de poner en un mismo sitio los símbolos de la dominación; lo que no ocurría en Europa en donde cada una de las sedes se encontraba en áreas distintas. Benevolo considera que la plaza representa el enfrentamiento del poder civil con el religioso; posición con la que difieren Bonet y Gutiérrez que la visualizan como la simbiosis de los dos poderes.

11 La relación entre la plaza mayor y el mercado era consustancial. No se podía pensar la una sin el otro; situación que se modificó con la política ilustrada que prefería los espacios abiertos.

12 El consumo anual de la ciudad de México era superior a las cantidades presentadas por Ajofrín, pues a la urbe entraban 4.255 .000 gallinas, 278.300 carneros, 125.000 patos, 50.600 puercos, 130.000 cargas de harina de trigo, 117.000 cargas de maíz, 130.000 cargas de pulque y 16.000 barriles de aguardiente y vino.

13 Durante el siglo XVIII, se postulaba que el número de habitantes era un índice de importancia de una ciudad y un indicador de su potencial económico. 


\section{FRONTERAS}

autor representaba la "nueva Athenas", pues de ella habían salido numerosos "hombres ilustres", lo que evidenciaba que eran falsas las acusaciones de que en América no había capacidad intelectual. Las actividades comerciales que se realizaban en el Volador eran de la misma importancia que las de la plaza mayor. La tercera plaza se encontraba fuera del corazón de la ciudad. En ella se encontraba el palacio del Santo Oficio de la Inquisición, la iglesia de los dominicos y la Real Casa de Aduana. El sacerdote le dedicó la mayor parte de su atención a la descripción de las actividades que se realizaban en la aduana, las mismas que evidenciaban los cambios administrativos que habían tenido lugar en esos años y la importancia económica que había alcanzado la ciudad.

Viera guardó silencio respecto del edificio de la Inquisición, lo que se explicaba por el hecho de que en las descripciones de las ciudades nunca se hacía alusión a las cuestiones referentes a la justicia civil o eclesiástica. En su exposición, el sacerdote trató de enfatizar el equilibrio que existía entre el orden terrenal y el espiritual; equilibrio que se manifestaba en todos los ámbitos de la vida: desde lo económico hasta lo educativo. Este énfasis tenía una intención: mostrar que el poder religioso y el civil podían compartir los mismos espacios y, que uno no debía tener preponderancia sobre el otro.

\section{Los servicios de la ciudad}

La narración de Viera mostraba una ciudad funcional que contaba con calles bien trazadas y amplias, que permitían la libre circulación de vehículos y de personas. El sacerdote mencionaba que circulaban más de 3.000 carruajes, los que demostraban tanto lujo, que podían ostentarse en la "más lucida Corte de Europa". La opinión del sacerdote no era exagerada. Gage había escrito cien años antes, que los carruajes de la capital novohispana eran "más espléndidos y costosos que los de la Corte de Madrid y de todos los otros reinos de Europa" (Ajofrín 58; Gage 178,182; Obregón 12) ${ }^{14}$. La mayor parte de las casas eran "magníficas" por su amplitud, comodidad, simetría y estilo arquitectónico. La ciudad no tenía problemas de abastecimiento, pues la comida se podía traer por medios acuáticos o terrestres, y el agua se conducía por medio de grandes acueductos. En ella había once colegios para la educación de los niños, una universidad y varios colegios que congregaban a los profesionistas. La riqueza que había alcanzado la urbe le permitía mantener varias instituciones de caridad, que se ocupaban del cuidado de los enfermos y de los desamparados. Es-

14 Gage afirmaba que en las calles podían circular seis carruajes de manera simultánea, pero Viera indicaba que lo podían hacer tres. 
tas instituciones no tenían nada que envidiar de las europeas. Para sostener las instituciones de caridad, la ciudad había dispuesto que se fundara un Monte de Piedad y una Real Lotería. Las reformas efectuadas por los Borbones tuvieron una buena acogida en el texto de Viera, quien consideraba que la instalación de las Reales Fábricas de Cigarros y de Pólvora tenían el objetivo de acrecentar la riqueza, tanto de la metrópoli, como de la ciudad de México.

El sacerdote advertía que las Reales Fábricas y el establecimiento de numerosos obrajes habían ocasionado la atracción de trabajadores a la capital del virreinato, lo que repercutió en el crecimiento de la ciudad, pues poblaciones como San Cristóbal de la Romita y Chapultepec pasaron a formar parte de la misma, debido a que en las calzadas que comunicaban estos pueblos con la urbe se asentaron pequeñas comunidades en las que vivían los trabajadores; razón por la que era difícil determinar en qué punto terminaba la ciudad y comenzaba el pueblo. La Candelaria y San Pablo sufrieron el mismo fenómeno, pues dejaron de ser barrios pequeños para convertirse en "casi pueblos por lo crecido de su vecindario". La apreciación de Viera era correcta, pues las reales fábricas contribuyeron a alterar el orden de la ciudad, debido a que concentraban enormes contingentes de hombres que tenían que buscar dónde vivir. Unos años después, Villarroel mencionaba que las reales fábricas eran las culpables del hacinamiento que se vivía en la ciudad de México (Lombardo 112 ; Serrera 8$)^{15}$.

\section{La ciudad paradisíaca}

De acuerdo con la visión de Viera, la ciudad de México era una urbe que ofrecía un perfecto equilibrio entre lo urbano y lo natural, situación que mostraba que la "Nueva Roma", transformada ahora en la "segunda Babilonia mexicana", tenía la virtud de saber comprender a la naturaleza, observarse en ella y entender que a través de su contemplación, se podía llegar a admirar la obra divina. Viera rompía con la idea renacentista de la ciudad como antítesis del campo; razón por la que no se limitaba a describir a la naturaleza, sino que la reinventaba para darle un cariz místico; lo que resultaba necesario para poder introducir la imagen de la ciudad de México como el "segundo paraíso". El sacerdote pensaba que la existencia de una gran cantidad de frutos demostraba que la ciudad de México podía considerarse "la nueva tierra de promisión", la "primavera del mundo" que esperaban los milenaristas, y a la que Singüenza

15 Por órdenes del visitador Gálvez, en 1766 se instaló la Real Fábrica de Cigarros. La mayoría de sus trabajadores eran indígenas que carecían de trabajo en sus lugares de origen. 


\section{FRONTERAS}

y Góngora hacía referencia en su Primavera indiana. Viera no fue el primero que asociaba la ciudad de México con el "paraíso celestial". Bernardo de Balbuena, Matías de Escobar, Francisco de Florencia, Miguel Sánchez, Bartolomé de Ita y Parra, Juan José Eguiara y Eguren y Miguel Venegas proponían que el paraíso se encontraba en tierras novohispanas. La virgen de Guadalupe, identificada como Eva, creaba un "nuevo paraíso" en la Nueva España, lo que demostraba que los novohispanos eran el pueblo elegido para guiar los destinos del nuevo mundo. Los novohispanos no fueron los únicos que establecieron una vinculación entre el paraíso y América, pues el peruano Antonio de la Calancha sostenía esa misma idea (Aguilera [187]; Brading [Orbe 92, 331, 409]; González [A lo invisible 83-84, "La naturaleza" 147, 149]; Kurnitzky y Echeverría [49, 54, 61]; Lafaye [103, 113, 123]; La Maza [La ciudad 58, 147]; Osorio [120, 144, 153,187]; Rubial [La plaza 16]; Serrera [87]).

Viera pensaba que la ciudad de México podía rendir culto perpetuo a la Virgen, pues contaba con 22 monasterios y 25 conventos, además de catorce parroquias, entre las que sobresalían la de San Miguel, Santa Catarina Mártir y la Santa Veracruz, las mismas que podían ser consideradas catedrales en algunos lugares de Europa. Obregón considera que esta afirmación era exagerada, pero el sacerdote buscaba mostrar que algunas parroquias formaban centros secundarios que tenían su propia organización. El que una parroquia se considerara una catedral evidenciaba la riqueza de la capital novohispana, pues podía presumir de tener cuatro catedrales a su servicio. La ciudad de México poseía iglesias que podían ser admiradas en la misma Roma, y entre ellas sobresalían las de San Francisco y Santo Domingo, que por su riqueza competían con la Catedral. Otro rasgo que demostraba la predilección divina por la ciudad de México era el elevado número de milagros que se habían obrado en ella. La capital del virreinato era privilegiada, pues en su seno había nacido Felipe de Jesús, Francisco Javier y Gregorio López (Rubial, "La Sociedad" 72; O'Gorman 8) ${ }^{16}$. La ciudad no sólo se distinguía por la elevada espiritualidad de sus habitantes, sino también por la cantidad de imágenes milagrosas con las que contaba, como la de la Señora de la Bala, la Virgen de los Remedios, la Virgen de la Piedad, el Cristo de Ixmiquilpa, la Virgen de la Asunción y la Virgen de la Concepción (Jiménez, "La palabra" 329-330) ${ }^{17}$. Sin embargo, el

16 Sobre los personajes mencionados puede verse Rubial (La santidad 93-128,133-135).

17 Los habitantes de la ciudad de México recurrían a lo sobrenatural, para mostrar que eran diferentes al resto de los pobladores de la Nueva España; situación que fue criticada por Joseph Antonio Rojas, quien fue denunciado en Zacatecas en 1768 debido a que había 
mayor portento con el que contaba la capital era la Virgen de Guadalupe, lo que mostraba que era una población elegida por Dios para maravillar al mundo y para salvaguardar de manera especial a América.

Eran numerosos los elogios que el autor prodigaba a la Virgen: "portento de los portentos", "epílogo de los prodigios", "breve complemento de los favores de la Divina Omnipotencia", "prothotypo verdadero del abreviado cielo", "torre inexpugnable", "sagrado propiciatorio", "iris de paz" y "áncora de nuestras esperanzas". La Virgen se convirtió en una figura simbólica que los criollos adoptaron como propia y como base de su identidad. Por los años en los que escribió Viera, la Virgen había alcanzado una posición trascendental en el culto novohispano. En 1737 fue nombrada patrona de la ciudad de México por el arzobispo y virrey Antonio de Vizarrón, gracias a su intercesión para acabar con la epidemia de Matlazáhuatl que mató a 40.000 personas en la capital. En 1746, el patronazgo de la Virgen se extendió a la América Septentrional. La exaltación de la guadalupana sirvió para que se le edificara un santuario y para que se construyera la calzada que unía el Tepeyac con la capital (Ajofrín 62; Gutiérrez y González 93; Osorio 140; Rubial, La Nueva 45; Serrera 16, 102). Viera hablaba con devoción del Tepeyac, una pequeña población que se encontraba "extramuros de la ciudad" pero que en realidad formaba parte de la misma, pues el lugar era frecuentado por innumerables "vecinos" de la capital y, por los habitantes de los pueblos cercanos, lo que había provocado que el lugar se considerara como "una de las calles de la ciudad". El sacerdote recurría a un artilugio para insertar el Tepeyac dentro de la ciudad de México, pues este "jardín del cielo" era un punto de paseo y de "devota romería". Aunque el Tepeyac estaba fuera de la traza de la capital, no representaba un impedimento para que extendiera su gracia divina hacia ella.

La vinculación entre estos lugares era necesaria, pues así se podían magnificar los dones de la ciudad. La unión del Tepeyac con la ciudad de México simbolizaba la entronización de la segunda, pues con ello no podía quedar duda de que era una población privilegiada y un digno regalo para la Virgen. La asociación entre la ciudad de México y la Virgen se observa en el emblema que Viera

escrito un folleto en el que cuestionaba que los habitantes de la ciudad de México creyeran "supersticiones" como la de la Virgen de la Bala, el Señor del Rebozo, el cristo de madera que lloraba sangre y la mano estampada, historias que, según el denunciado, mostraban la piedad de un pueblo "ignorante" y, la picardía de un clero que sostenía las creencias, para obtener pingües ganancias. 


\section{FRONTERAS}

colocó en la anteportada de su libro (Burke 60-61; Praz 18, 71, 253)18. En ella, los ángeles parecen ofrecerle la ciudad a la Virgen, quien la recibe agradecida y asume el compromiso de protegerla. La escena es observada con atención por un águila coronada, que en su pecho sostiene el escudo de la ciudad. Al pie de la estampa se observa la siguiente leyenda: "En Guadalupe, María, de la gran México es guía". Cuatro banderolas rodean la ilustración, las mismas que contienen la inscripción: "Non felicit taliter omni nationi", "arma", "nostra" "militiae"19. Como fiel devoto de la virgen, el sacerdote pensaba que ella constituía el mayor tesoro con el que contaban los "americanos". Los "mexicanos" debían sentirse privilegiados, pues Dios les había otorgado el mayor "regalo celestial", razón por la que se le debía rendir homenaje perpetuo a la "Reina del cielo". La elección de la ciudad de México como asiento de la Virgen denotaba que ésta estaba destinada a ser la cabeza del continente americano. Tanto los europeos como los demás americanos debían darse cuenta de la importancia de la capital del virreinato; importancia que no sólo se manifestaba en el ámbito terrenal, sino también en el espiritual. El autor buscaba que su libro se constituyera en una muestra de la veneración que sentía por la Virgen y por la ciudad de México, dos entidades que eran representativas de una misma idea: la búsqueda de una identidad del criollismo mexicano.

\section{Consideraciones finales}

El texto de Viera constituye una de las últimas manifestaciones de escritos barrocos sobre la ciudad de México. Lo que lo diferencia de otros libros escritos en la misma época es que daba cuenta de los cambios que experimentaba la capital del virreinato. Una urbe que en la década de los setenta del siglo XVIII sufrió transformaciones en su estructura espacial y administrativa, los cuales respondían a los postulados derivados de la Ilustración. El objetivo primario del sacerdote era demostrar la magnificencia de la capital del virreinato. Una urbe que tenía mayores blasones que las ciudades mitológicas y que se comparaba en belleza e

18 Un emblema es un dibujo alegórico que se acompaña de un lema explicativo, y cuya finalidad es difundir una verdad moral de manera intuitiva. Los emblemas tuvieron una amplia difusión en el siglo XVIII, centuria en la que se alcanzó el clímax de las imágenes, pues se les consideraba un método de enseñanza excepcional. El predominio de la imagen manifiesta la presencia de una lógica particular de pensamiento y de la expresión figurada.

19 Una segunda ilustración se encuentra al final del texto, en la que se observa una vista de la plaza mayor de la ciudad y un personaje que parece que se dedica a escribir o a pintar. La edición de 1952 contiene los dos grabados, en tanto que la de 1992 carece de la imagen de la Guadalupana y el dibujo final se encuentra mutilado. 
importancia con las más importantes de Europa. El sacerdote se inscribe dentro de la corriente criolla que buscaba demostrar el orgullo americano por su patria y por su continente, por lo que no debe sorprender que tratara de magnificar a la ciudad de México. Una urbe que, desde su perspectiva, había sido escogida por Dios y por la Virgen para demostrar las virtudes americanas. Al igual que los demás intelectuales criollos, Viera utilizó la religión para fundamentar sus ideas respecto a que los americanos no sólo eran iguales que los europeos, sino que los superaban. El autor tenía pleno conocimiento del funcionamiento de la capital del virreinato y de sus alrededores, lo que le otorgó la autoridad necesaria para describir los sitios más representativos de una de las poblaciones más populosas de América. Viera considera que sus edificios, iglesias, colegios y frutos de la tierra poseían todas las virtudes imaginables. La ciudad de México, bajo la pluma del sacerdote, se presentaba perfecta en todos los sentidos. Era una población con numerosas cualidades y en donde no se manifestaba la perversión en las costumbres, tal como las que contaban algunos cronistas y viajeros.

En la narración de Viera se advertía que los habitantes de la capital habían logrado un alto nivel de vida, lo que evidenciaba que la ciudad de México era la "tierra de [las] maravillas". Si se piensa que este escrito estaba concebido para impresionar al mundo europeo y a los viajeros, se puede entender la posición de un sacerdote que en su afán de acreditar la magnificencia de la tierra novohispana realizó numerosos elogios que tendían al exceso. Todo era permitido cuando se trataba de superar a Europa. La ciudad que presentaba Viera tenía la particularidad de ser terrenal y celestial. El autor buscaba mostrar que la ciudad terrenal era perfecta, para justificar el argumento de que Dios la había elegido como asiento de la Virgen de Guadalupe. La idea de una ciudad celestial transplantada al suelo americano, se puede considerar como uno de los productos criollos más acabados. Viera y otros autores concebían que la opulencia de la ciudad de México se debía a los dones que el cielo le había otorgado. La "ciudad paradisíaca" formaba parte de un imaginario que se cargaba de figuras míticas y religiosas en plena armonía. Una urbe que, sin ningún problema, pasaba de ser la "nueva Roma" a la "nueva Babilonia" y que, gracias a los atributos de ella permitía que en la tierra se instalara un pedazo del paraíso, concepción que fue utilizada por los criollos novohispanos, para tratar de mostrar el lugar que creían que les correspondía en el mundo. 


\section{Bibliografía}

Abascal, Fernando. "Traza, desarrollo urbano de la ciudad Colonial y tendencias arquitectónicas". La muy noble y leal ciudad de México. T. 2. Isabel Tovar y Magdalena Mas, coords. México: Departamento del Distrito Federal; Universidad Iberoamericana, Conaculta, 1994.

Aguilera, Javier. Fundación de ciudades hispanoamericanas. Madrid: Mapfre, 1994.

Ajofrín, Francisco de. Diario de viaje a la Nueva España. México: SEP, 1986.

Alberro, Solange. Del gachupín al criollo o de cómo los españoles de México dejaron de serlo. México: El Colegio de México, 1992.

Arenas, Isabel. "Mecenazgo femenino y desarrollo conventual en Puebla de los Ángeles (1690-1711)”. Manifestaciones religiosas en el mundo colonial americano. Instituciones y culto a María. T. 2. Clara García y Manuel Ramos, coords.. México: UIA, INAH, CONDUMEX, 1994.

Armillas, José A. y Enrique Solano. La España Ilustrada del Siglo XVIII. Madrid: Anaya, 1988.

Baker, Edward. Materiales para escribir Madrid. Literatura y espacio urbano de Moratín a Galdós. Madrid: Siglo XXI, 1991.

Benítez, Fernando. Historia de la ciudad de México, t. 4. México: Salvat, 1984.

Bonet, Antonio. El Urbanismo en España e Hispanoamérica. Madrid: Cátedra, 1991.

Benevolo, Leonardo. Diseño de la ciudad. El arte y la ciudad moderna del siglo XV al XVIII. T. 3- 4. Barcelona: Gustavo Gili, 1982.

Brading, David A. Los orígenes del nacionalismo mexicano. México: SEP, 1973. 
Brading, David A. Orbe Indiano. De la monarquía católica a al República criolla. 1492-1867. México: Fondo de Cultura Económica, 1991.

Burke, Peter. Visto y no visto. El uso de la imagen como documento histórico. Barcelona: Crítica, 2001.

Carrillo, Rafael. El arte barroco en México. Desde sus inicios, hasta el esplendor de los siglos XVII y XVIII. México: Panorama, 1982.

Carreño, Antonio. "Naufragios de Alvar Núñez Cabeza de Vaca: una retórica de la crónica colonial". Revista Iberoamericana 3.14 (1995).

Castañon, Adolfo y Eduardo Millán. Historia de la literatura mexicana. El Barroco. T. 4. México: SEP; Somos, 1982.

Castro, Felipe. Nueva ley y nuevo rey. Reformas borbónicas y rebelión popular en la Nueva España. México: El Colegio de Michoacán; Universidad Nacional Autónoma de México, 1996.

Clavijero, Francisco Javier. Historia Antigua de México. México: Porrúa, 1987.

Dávalos, Marcela. Basura e ilustración. La limpieza de la ciudad de México a fines del siglo XVIII. México: Instituto Nacional de Antropología e Historia; Departamento del Distrito Federal, 1997.

Davis, Alexander V. El Siglo de Oro de la Nueva España (siglo XVIII). México: Polis, 1945.

Dondis, D. A. La sintaxis de la imagen. Introducción al alfabeto visual. Barcelona: Gustavo Gili, 1992.

Gage, Tomás. Nuevo Reconocimiento de las Indias Occidentales. México: Conafe, 1982.

Galán, José Luis "Madrid y los cementerios en el siglo XVIII: el fracaso de una reforma". Carlos III, Madrid y la Ilustración. Contradicciones de un proyecto reformista, por Galán. Madrid: Siglo XXI, 1988.

Galindo, Jesús. La plaza mayor de la ciudad de México. México: Imprenta del Museo Nacional de Arqueología, Historia y Etnología, 1914. 


\section{FRONTERAS}

de la historia

Vol.13-1 / 2008

Gerbi, Antonello. La disputa del Nuevo Mundo. Historia de una polémica. 1750-1900. México: Fondo de Cultura Económica, 1993.

González, César. "La naturaleza en el imaginario medieval". Morphé 4.6 (1994).

-. A lo invisible por lo visible. Imágenes del occidente medieval. México: Universidad Nacional Autónoma de México, 1995.

González, Pablo. La Literatura perseguida en la crisis de la Colonia. México: Fondo de Cultura Económica; Colegio de México, 1958.

Gortari, Hira de y Regina Hernández. La ciudad de México y el Distrito Federal. Una historia compartida. México: Instituto Mora; Departamento del Distrito Federal, 1988.

Gutiérrez, Ramón. "Ciudades y pueblos: ocupación espacial y diferencias socioeconómicas". La ciudad iberoamericana hasta 1573. Madrid: Consejo Superior de los Colegios de Arquitectos de España; Comisión Nacional del Quinto Centenario; Junta de Andalucía, 1987. T. 1 de Historia Urbana de Iberoamérica. Francisco de Solano, cir. 3 t. 1987-1992.

Gutiérrez, María Teresa y Jorge González. Geohistoria de la ciudad de México (siglos XIV a XIX). México, Universidad Nacional Autónoma de México; Instituto de Geografía, 2002.

Hardoy, Enrique. "La forma de las ciudades coloniales en la América española". Estudio sobre la ciudad Iberoamericana. Francisco de Solano, coord. Madrid: Consejo Superior de Investigaciones Científicas, 1983.

Jiménez, Rogelio. "La palabra reprimida. El control social sobre el imaginario del más allá. Siglos XVII-XVIII”. Trabajo de grado de doctorado. Centro de Investigaciones y Estudios Superiores en Antropología Social, 2006.

Jáuregui, Ernesto. El clima de la ciudad de México. México: Universidad Nacional Autónoma de México; Plaza y Valdés; Instituto de Geografía, 2000. 
Kingman, Eduardo. Introducción. Las ciudades en la historia por Kingman, coord. Quito: Universidad Central de Ecuador; Conuep; Centro de Investigaciones Ciudad, 1989.

Kurnitzky, Horst y Bolívar Echeverría. Conversaciones sobre lo barroco. México: Universidad Nacional Autónoma de México, 1993.

Lafaye, Jacques. Quetzacóatl y Guadalupe. La formación de la conciencia nacional en México. México: Fondo de Cultura Económica, 1983.

Lamadrid, Alberto. "Guías de forasteros y calendarios mexicanos de los siglos XVIII y XIX, existentes en la Biblioteca Nacional de México". Boletín del Instituto de Investigaciones Bibliográficas 6 (juliodiciembre de 1971): 9-135.

La Maza, Francisco de. La ciudad de México en el siglo XVII. México: Fondo de Cultura Económica; SEP, 1985.

-. El guadalupanismo mexicano. México: Fondo de Cultura Económica; SEP, 1984.

Lepetit, Bernard. Las ciudades en la Francia moderna. México: Instituto Mora, 1996.

Leonard, Irving A. La época barroca en el México Colonial. México: Fondo de Cultura Económica, 1996.

Lombardo, Sonia. "La reforma urbana en la ciudad de México del siglo XVIII". La ciudad concepto y obra. México: Universidad Nacional Autónoma de México; Instituto de Investigaciones Estéticas, 1987.

Lomelí, Leonardo. Breve historia de Puebla. México: El Colegio de México; Fondo de Cultura Económica; Fideicomiso Historia de las Américas, 2001.

Loreto, Rosalía. "La fiesta de la Concepción y las identidades colectivas, Puebla (1619-1636)". Manifestaciones religiosas en el mundo colonial americano. Instituciones y culto a María. T. 2. Clara García y Manuel Ramos, coords. México: UIA, INAH, Condumex, 1994. 


\section{FRONTERAS}

de la fistoria

Vol.13-1 / 2008

Lowe, Donald M. Historia de la percepción burguesa. México: Fondo de Cultura Económica, 1986.

Lozoya, Xavier. Plantas y luces en México. La Real Expedición Cientifica a Nueva España (1787-1803). Barcelona: Serbal, 1984.

Malamud, Carlos. "La estructura urbana iberoamericana". Historia Urbana de Iberoamérica. Francisco de Solano, dir. Madrid: Consejo Superior de los Colegios de Arquitectos de España; Comisión Nacional del Quinto Centenario; Junta de Andalucía, 1987.

Manrique, Jorge Alberto. "Barroco mexicano: ¿Qué tan barroco? ¿Qué tan mexicano?". Memoranda 3.15 (1991).

- "La ciudad: de la civilización a la barbarie". La ciudad concepto y obra: México: Universidad Nacional Autónoma de México; Instituto de Investigaciones Estéticas, 1987.

Marchetti, Giovanni. Cultura indígena e integración nacional. La "Historia Antigua de México" de Francisco Javier Clavijero. Xalapa, México: Universidad Veracruzana, 1986.

Margadant, Floris. "Las ciudades novohispanas ante el derecho". La ciudad concepto y obra. México: Universidad Nacional Autónoma de México; Instituto de Investigaciones Estéticas, 1987.

Moreno, Heriberto. Introducción. Diario de viaje a la Nueva España, por Francisco de Ajofrín. México: SEP, 1986.

Morse, Richard. "Introducción a la Historia Urbana de Hispanoamérica". Estudio sobre la ciudad Iberoamericana. Francisco de Solano, coord. Madrid: Consejo Superior de Investigaciones Científicas, 1983.

Obregón, Gonzalo. Presentación. Breve compendiosa narración de la ciudad de México, corte y cabeza de toda la América septentrional, que a instancias de un amigo bosquejo el B.D. Juan de Viera presbitero de este arzobispado y mayordomo administrador de las rentas del real y más antiguo Colegio de San Pedro y San Pablo, y las de san Yldefonso y las de su anexo que era el Real 
de Christo, por Juan de Viera. México: Guarania, 1952. México: Instituto Mora, 1992.

O'Gorman, Edmundo. Meditaciones sobre el criollismo. Discurso de ingreso en la Academia Mexicana de la Lengua correspondiente a la Española. México: Condumex, 1970.

Orozco, Manuel. Memoria para el plano de la ciudad de México. México: Imprenta de Santiago White, 1867.

Osorio, Ignacio. El sueño criollo. José Antonio de Villerías y Roelas (16951728). México: Universidad Nacional Autónoma de México; Instituto de Investigaciones Filológicas, 1991.

Praz, Mario. Imágenes del Barroco (Estudios de emblemática). Madrid: Siruela, 1989.

Penny, William T. "A sketch of the customs and society of Mexico, in a series of familiar letters; and journal of travels in the interior during the years 1824, 1825 and 1826". Zaguán abierto al México republicano (1820-1830), Juan A. Ortega y Medina. México: Universidad Nacional Autónoma de México, 1987.

Puccini, Dario. Una mujer en soledad. Sor Juana Inés de la Cruz, una excepción en la cultura y en la literatura barroca. México: Fondo de Cultura Económica, 1997.

Quirarte, Vicente. Presentación. Guía de forasteros y repertorio de conocimientos útiles, por Juan Nepomuceno Almonte. México: Instituto Mora, 1997.

Ramos, Manuel. "La Iglesia y la ciudad de México en el virreinato". La muy noble y leal ciudad de México. T. 2. Isabel Tovar y Magdalena Mas, coords. México: Departamento del Distrito Federal; Universidad Iberoamericana; Conaculta, 1994.

Rasmussen, Steen Eiler. La experiencia de la arquitectura. Sobre la percepción de nuestro entorno. Madrid: Mairea; Celeste, 2000.

Rivera, Óscar. "Niveles diegéticos en las crónicas de Arzans". Revista Iberoamericana 52.134 (1986): 9-28. 


\section{FRONTERAS}

de la fistoria

Rubial, Antonio. "La Sociedad novohispana de la ciudad de México". La muy noble y leal ciudad de México. T. 2. Isabel Tovar y Magdalena Mas, coords. México: Departamento del Distrito Federal; Universidad Iberoamericana; Conaculta, 1994.

—. La Nueva España. México: Conaculta, 2002.

- La plaza, el palacio y el convento. La ciudad de México en el siglo XVII. México: Conaculta, 1998.

- La santidad controvertida. Hagiografía y conciencia criolla alrededor de los venerables no canonizados de Nueva España. México: Fondo de Cultura Económica; Universidad Nacional Autónoma de México, 1999.

Serrera, Ramón María. Estudio preliminar. Suplemento al Theatro Americano, por Joseph Antonio Villaseñor y Sánchez. México: Universidad Nacional Autónoma de México; Consejo Superior de Investigaciones Científicas, 1980.

Silva, Jorge. Presentación. Breve compendiosa narración de la ciudad de México, corte y cabeza de toda la América septentrional, que a instancias de un amigo bosquejo el B.D. Juan de Viera presbitero de este arzobispado y mayordomo administrador de las rentas del real y más antiguo Colegio de San Pedro y San Pablo, y las de san Yldefonso y las de su anexo que era el Real de Christo, por Juan de Viera. México: Instituto Mora, 1992.

Solano, Francisco de. "El núcleo urbano iberoamericano: proceso de larga duración". La ciudad iberoamericana hasta 1573. Madrid: Consejo Superior de los Colegios de Arquitectos de España; Comisión Nacional del Quinto Centenario; Junta de Andalucía, 1987. T. 1 de Historia Urbana de Iberoamérica. Francisco de Solano, dir. 3 t. 1987-1992.

-. Ciudades hispanoamericanas y pueblos de indios. Madrid: Consejo Superior de Investigaciones Científicas, 1990.

- Las voces de la ciudad. México a través de sus impresos (1539-1821). Madrid: Consejo Superior de Investigaciones Científicas, 1994. 
Solano, Francisco de. Normas y leyes de la ciudad hispanoamericana. 14921600. Madrid: Consejo Superior de Investigaciones Científicas, 1996.

—. "Las voces de la ciudad de México: Aproximación a la historiografía de la ciudad de México". La ciudad concepto y obra. México: Universidad Nacional Autónoma de México; Instituto de Investigaciones Estéticas, 1987.

Taylor, William B. Embriaguez, homicidio y rebelión en las poblaciones coloniales mexicanas. México: Fondo de Cultura Económica, 1987.

Urbina, Luis G. La vida literaria en México. Madrid: Imprenta Sáez Hermanos, 1917.

Valle, Artemio de. Historia de la ciudad de México según los relatos de sus cronistas. México: Pedro Herrero, 1939.

Viera, Juan de. Breve compendiosa narración de la ciudad de México, corte y cabeza de toda la América septentrional, que a instancias de un amigo bosquejo el B.D. Juan de Viera presbitero de este arzobispado y mayordomo administrador de las rentas del real y más antiguo Colegio de San Pedro y San Pablo, y las de san Yldefonso y las de su anexo que era el Real de Christo, México: Guarania, 1952. México: Instituto Mora, 1992.

Villa Sánchez, Juan. Puebla sagrada y profana. Puebla, México: Impreso en la casa del ciudadano José María Campos, 1835.

Villaseñor, Joseph Antonio. Theatro Americano. Descripción general de los reynos y provincias de la Nueva España, y sus jurisdicciones. México: Imprenta de la Vda. de Don Joseph Bernardo de Hogal, 1745.

Viqueira, Juan Pedro. ¿Relajados o reprimidos? Diversiones públicas y vida social en la ciudad de México durante el siglo de las Luces. México: Fondo de Cultura Económica, 1987.

Fecha de recepción: 29 de noviembre de 2007.

Fecha de aprobación: 15 de mayo de 2008. 